\title{
Posterior Reversible Leukoencephalopathy Syndrome Associated with Pazopanib
}

\author{
Robert Foerster $^{\mathrm{a}} \quad$ Thomas Welzel $^{\mathrm{a}} \quad$ Juergen Debus $^{\mathrm{a}} \quad$ Carsten Gruellich $^{\mathrm{b}}$ \\ Dirk Jaeger ${ }^{b}$ Karin Potthoff ${ }^{a, b}$ \\ ${ }^{a}$ Department of Radiation Oncology, University Hospital Heidelberg, and ${ }^{\mathrm{b}}$ National Center \\ for Tumor Diseases, University of Heidelberg, Heidelberg, Germany
}

\section{Key Words}

Hypertension · Pazopanib · Posterior reversible encephalopathy syndrome $\cdot$ Reversible posterior leukoencephalopathy syndrome $\cdot$ Tyrosine kinase inhibitors

\begin{abstract}
A 62-year-old female patient with metastatic renal cell carcinoma under third-line treatment with pazopanib for 8 weeks suddenly developed severe headaches, grand mal seizures and paresis of the left arm in combination with gait instability as well as nausea and vomiting during her vacation abroad. The emergency physician measured systolic blood pressure values over $300 \mathrm{~mm} \mathrm{Hg}$ and suspected a stroke. The CT imaging without contrast agent in a local hospital did not show any pathologic findings despite bone metastases. The colleagues suspected cerebral metastases or meningeosis carcinomatosa and referred the patient to our department for further diagnostics and treatment planning. An MRI scan ruled out the suspected cerebral metastases or meningeosis carcinomatosa, but showed signs of reversible posterior leukoencephalopathy syndrome (RPLS) in the form of band-like hyperintensities as a sign of cytotoxic edema in the gray and white matter of the left parietal lobe. The patient then reported that similar blood pressure values had been measured shortly after the start of a first-line therapy with sunitinib, so that we discontinued the current treatment with pazopanib. Within 6 days the neurologic symptoms vanished and the patient was discharged. An intermittent hypertension persisted. A follow-up MRI 3 weeks later showed an RPLStypical cortical infarction in the affected area. RPLS should be considered as the actual reason for neurologic findings in hypertensive patients with known metastatic cancers under tyrosine kinase inhibitor therapy.
\end{abstract}




\section{Introduction}

Tyrosine kinase inhibitors (TKIs) are a relatively new treatment modality for the treatment of metastatic renal cell carcinoma. Although they have shown promising results, their use is often limited due to adverse reactions. Pazopanib, which is the most recently approved drug for metastatic renal cell carcinoma, is an oral small-molecule TKI that inhibits vascular endothelial growth factor (VEGF) receptors 1, 2, and 3, c-kit, and platelet-derived growth factor receptors alpha and beta. We report on a case of malignant hypertension and occurrence of reversible posterior leukoencephalopathy syndrome (RPLS) in a 62-year-old female patient treated with pazopanib for metastatic renal cell carcinoma.

\section{Case Report}

A 62-year-old female patient with known papillary renal cell carcinoma diagnosed in 2004 and under third-line treatment with pazopanib for 8 weeks suddenly developed severe headaches, grand mal seizures and paresis of the left arm in combination with gait instability as well as nausea and vomiting during her vacation abroad. The emergency physician measured systolic blood pressure values over $300 \mathrm{~mm} \mathrm{Hg}$ and suspected a stroke. Therefore, the patient was hospitalized in a local hospital where she received a CT scan without contrast agent. The CT imaging, however, did not show any pathologic findings despite bone metastases. The patient's husband meanwhile had organized a medical transport back to Germany. Due to the fact that she had been previously treated in our comprehensive cancer center at the University Hospital of Heidelberg and the colleagues abroad had suspected newly formed metastases or meningeosis carcinomatosa clinically mimicking cerebral metastases, she was admitted to our department of radiation oncology for further diagnostics and treatment planning.

At the time of admission, the patient was somnolent and not able to communicate with us because she had received large quantities of intravenous diazepam as an anticonvulsive measure on the plane. We initiated an anticonvulsive therapy with levetiracetam $250 \mathrm{mg}$ twice a day and antiedematous treatment with dexamethasone $8 \mathrm{mg}$ thrice a day. The next day, the patient was fully awake but showed significant anterograde amnesia from the onset of the headaches, psychomotoric deceleration and persistent gait instability. A detailed neurologic examination with EEG by our colleagues showed no signs of epilepsy. The initially suspected brain metastases or meningeosis carcinomatosa were ruled out with an MRI scan which, however, showed signs of RPLS in the form of band-like hyperintensities as a sign of cytotoxic edema in the gray and white matter of the left parietal lobe (fig. 1). The hypertension persisted with values of up to $220 / 120 \mathrm{~mm} \mathrm{Hg}$ under triple antihypertensive therapy with metoprolol, amlodipine and candesartan. The patient reported that similar values had been measured shortly after the start of a first-line therapy with sunitinib about 1 year before. With pazopanib being known to cause hypertension we discontinued the current treatment [1]. During her 6-day stay in our department the neurologic findings completely vanished and we were able to discharge her. A follow-up MRI 3 weeks later showed that the patient had developed an RPLS-typical cortical infarction [2] in the affected area (fig. 2). Fortunately she remained without any neurologic symptoms. An intermittent hypertension, however, persisted with values of up to $180 / 100 \mathrm{~mm} \mathrm{Hg}$ in this short follow-up. A cardiologic checkup had meanwhile ruled out cardiac genesis. 
Foerster et al.: Posterior Reversible Leukoencephalopathy Syndrome Associated with Pazopanib

\section{Discussion}

VEGF inhibitors and TKIs which block the VEGF receptor itself are known to be associated with hypertension and other cardiovascular symptoms $[3,4]$. For sunitinib $30 \%$ of patients were reported to develop hypertension under therapy [5] and the phase III trial on the data of which pazopanib was approved for treatment of metastatic renal cell carcinoma by the US Food and Drug Administration in October 2009 reported that $40 \%$ of patients treated with pazopanib developed hypertension [6]. Currently the exact mechanism of antiVEGF therapies causing high blood pressure remains unknown, but increased peripheral resistance and vascular tone may play a role [4]. Hypertension has been described as the cause of RPLS [7], and various case reports have been published about patients developing RPLS under sunitinib, sorafenib and bevacizumab therapy [8-15]. Only recently two cases of RPLS under treatment with pazopanib have been reported [16, 17]. The history of our patient shows that if hypertension occurs under treatment with one TKI there is a strong possibility that it will occur under another TKI as well. Although symptoms of RPLS usually disappear within a few days to 1 month [11], blood pressure values should be closely monitored under TKI therapy to prevent malignant hypertension and its consequences. Furthermore, with our case being already the third published report on RPLS under pazopanib treatment and one of multiple case reports on RPLS under TKI therapy in general, RPLS clinically mimicking cerebral metastases should always be considered as the actual reason for neurologic findings in patients with known metastatic cancers under TKI therapy.

To enable a better risk stratification for the patients, further investigations on the mechanisms of how TKIs cause hypertension are necessary. However, anti-VEGF therapy-induced hypertension may be an indicator for an improved outcome. Both progression-free survival and overall survival were significantly increased in patients developing hypertension under treatment with anti-VEGF-directed substances $[18,19]$. Hence, development of hypertension is no contraindication to TKI treatment. If required, patients should receive antihypertensive therapy.

\section{References}

1 GlaxoSmithKline: Votrient (pazopanib) tablets prescribing information. 2012.

$\checkmark 2$ Covarrubias DJ, Luetmer PH, Campeau NG: Posterior reversible encephalopathy syndrome: prognostic utility of quantitative diffusion-weighted MR images. AJNR Am J Neuroradiol 2002;23:1038-1048.

3 Cohen RB, Oudard S: Antiangiogenic therapy for advanced renal cell carcinoma: management of treatmentrelated toxicities. Invest New Drugs 2012;30:2066-2079.

-4 Veronese ML, Mosenkis A, Flaherty KT, Gallagher M, Stevenson JP, Townsend RR, O’Dwyer PJ: Mechanisms of hypertension associated with BAY 43-9006. J Clin Oncol 2006;24:1363-1369.

-5 Motzer RJ, Hutson TE, Tomczak P, Michaelson MD, Bukowski RM, Oudard S, Negrier S, Szczylik C, Pili R, Bjarnason GA, Garcia-del-Muro X, Sosman JA, Solska E, Wilding G, Thompson JA, Kim ST, Chen I, Huang X, Figlin RA: Overall survival and updated results for sunitinib compared with interferon alfa in patients with metastatic renal cell carcinoma. J Clin Oncol 2009;27:3584-3590.

-6 Sternberg CN, Davis ID, Mardiak J, Szczylik C, Lee E, Wagstaff J, Barrios CH, Salman P, Gladkov OA, Kavina A, Zarba JJ, Chen M, McCann L, Pandite L, Roychowdhury DF, Hawkins RE: Pazopanib in locally advanced or metastatic renal cell carcinoma: results of a randomized phase III trial. J Clin Oncol 2010;28:1061-1068.

7 Hinchey J, Chaves C, Appignani B, Breen J, Pao L, Wang A, Pessin MS, Lamy C, Mas JL, Caplan LR: A reversible posterior leukoencephalopathy syndrome. N Engl J Med 1996;334:494-500.

-8 Dogan E, Aksoy S, Arslan C, Dede DS, Altundag K: Probable sorafenib-induced reversible encephalopathy in a patient with hepatocellular carcinoma. Med Oncol 2010;27:1436-1437.

-9 Hadj JO, Braven RD, Tillier C, Schrijver HM, Verheul HM, van der Vliet HJ: Reversible posterior leukoencephalopathy syndrome during sunitinib therapy for metastatic renal cell carcinoma. Oncol Lett 2012;3:1293-1296.

10 Martin G, Bellido L, Cruz JJ: Reversible posterior leukoencephalopathy syndrome induced by sunitinib. J Clin Oncol 2007;25:3559. 


\section{Case Reports in Oncology}

\begin{tabular}{l|l}
\hline Case Rep Oncol 2013;6:204-208 & \\
\hline DOI: 10.1159/000350742 & $\begin{array}{l}\text { @ 2013 S. Karger AG, Basel } \\
\text { www.karger.com/cro }\end{array}$ \\
\hline
\end{tabular}

Foerster et al.: Posterior Reversible Leukoencephalopathy Syndrome Associated with Pazopanib

11 Padhy BM, Shanmugam SP, Gupta YK, Goyal A: Reversible posterior leucoencephalopathy syndrome in an elderly male on sunitinib therapy. Br J Clin Pharmacol 2011;71:777-779.

12 Sclafani F, Giuseppe G, Mezynksi J, Collins C, Crown J: Reversible posterior leukoencephalopathy syndrome and bevacizumab in breast cancer. J Clin Oncol 2012;30:e257-e259.

13 Kapiteijn E, Brand A, Kroep J, Gelderblom H: Sunitinib induced hypertension, thrombotic microangiopathy and reversible posterior leukencephalopathy syndrome. Ann Oncol 2007;18:1745-1747.

14 Cumurciuc R, Martinez-Almoyna L, Henry C, Husson H, de Broucker T: Posterior reversible encephalopathy syndrome during sunitinib therapy. Rev Neurol (Paris) 2008;164:605-607.

15 Chen A, Agarwal N: Reversible posterior leucoencephalopathy syndrome associated with sunitinib. Intern Med J 2009;39:341-342.

16 Chelis L, Souftas V, Amarantidis K, Xenidis N, Chamalidou E, Dimopoulos P, Michailidis P, Christakidis E, Prassopoulos P, Kakolyris S: Reversible posterior leukoencephalopathy syndrome induced by pazopanib. BMC Cancer 2012;12:489.

17 Asaithambi G, Peters BR, Hurliman E, Moran BP, Khan AS, Taylor RA: Posterior reversible encephalopathy syndrome induced by pazopanib for renal cell carcinoma. J Clin Pharm Ther 2013;38:175-176.

18 Rini BI, Halabi S, Rosenberg JE, Stadler WM, Vaena DA, Archer L, Atkins JN, Picus J, Czaykowski P, Dutcher J, Small EJ: Phase III trial of bevacizumab plus interferon alfa versus interferon alfa monotherapy in patients with metastatic renal cell carcinoma: final results of CALGB 90206. J Clin Oncol 2010;28:2137-2143.

19 Ravaud A, Sire M: Arterial hypertension and clinical benefit of sunitinib, sorafenib and bevacizumab in first and second-line treatment of metastatic renal cell cancer. Ann Oncol 2009;20:966-967.

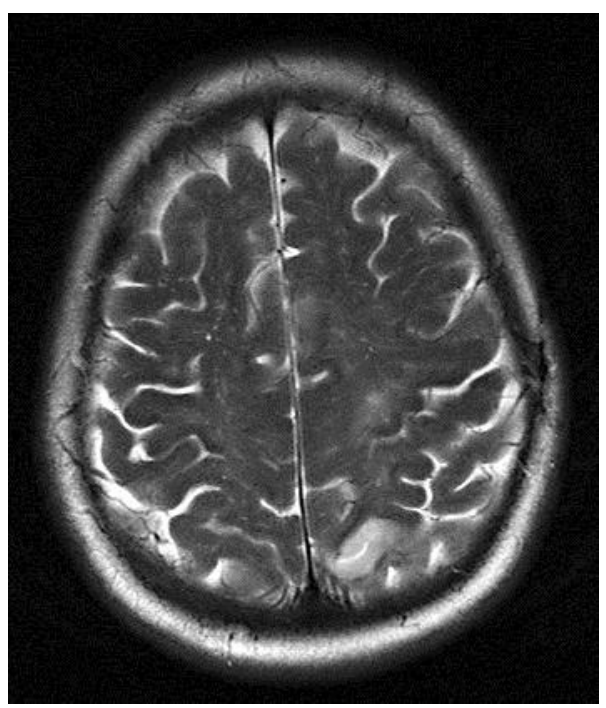

Fig. 1. T2-weighted image showing band-like hyperintensities in the gray and white matter of the parietal lobe. 


\section{Case Reports in Oncology}

Case Rep Oncol 2013;6:204-208

Foerster et al.: Posterior Reversible Leukoencephalopathy Syndrome Associated with

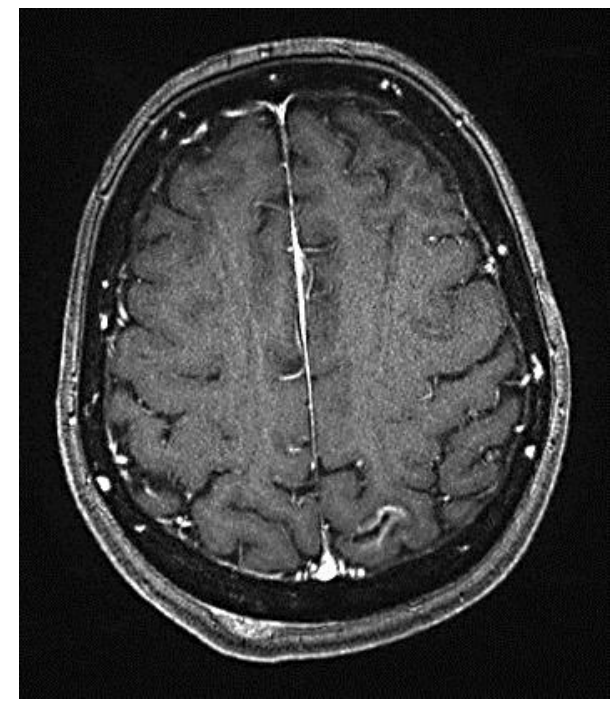

Fig. 2. T1-weighted image with gadolinium showing a cortical infarction.
DOI: 10.1159/000350742

Pazopanib www.karger.com/cro (c) 2013 S. Karger AG, Basel 